Readmore Publications

Research Publications

Routledge, Chapman and Hall

Roy Young Bookseller, Inc.

Russ Bassett

Rutgers University-SCLIS

Salem Press, Inc.

Scarecrow Press

Scholarly Book Center

SilverPlatter Information, Inc.

Sobeco Group, Inc.

Sociological Abstracts, Inc.

Spacesaver Corporation
Springer-Verlag New York, Inc.

Taylor \& Francis, Inc.

UMI

United Nations-Publications

University Publications of America

Van Nostrand Reinhold Company

VCH Publishers, Inc.

W.H. Freeman and Company

Wiley

Women's History Research Center

Wright Investors' Service-WORLDSCOPE

Yankee Book Peddler, Inc.

\title{
Special Events
}

\section{Poster sessions}

Forty poster sessions will be presented in the exhibit hall on Thursday and Friday. Poster sessions provide an opportunity for the informal exchange of information. Presenters place materials (graphs, diagrams, pictures, data and narrative text) on bulletin boards and discuss their presentations with conference attendees. The presentations will cover a broad range of subjects and present research findings, innovative programs and solutions for problems.

\section{Take me out to the ACRL Game!}

Come out to the ball game on April 5, 7:35 p.m., to see the Cincinnati Reds play the World Series Champs, the Los Angeles Dodgers. It's "ACRL Night at the Reds" and if we get a good crowd for the game a lucky ACRL member could throw out the ceremonial first pitch and sing the National Anthem! Wear your favorite library sweat shirt and join your ACRL friends at the Riverfront Stadium, just minutes from downtown hotels. The tickets for the lower level box seats (off third base) are $\$ 8.50$ plus $\$ 1.00$ postage and handling. Deadline for ticket orders is February 28, 1989. Use the order form in the preliminary program to reserve your tickets.

\section{Treasures from the ALA A rchives}

The ALA Archives at the University of Illinois, Urbana-Champaign, is a treasure that few librarians have found. The University Archivist, Maynard Brichford, will bring some of the treasures to you in Cincinnati. See some of the photos, documents and artifacts from our first century at the display in the West Exhibit Hall.

\section{Luncheon in honor of academic leaders}

Edward G. Holley will speak on "Building a Firm Foundation: ACRL Leadership, 1939-1989" at a luncheon in honor of past ACRL presidents and executive directors. You can have lunch with these outstanding leaders on Thursday, April 6, 12:30 p.m.-2:00 p.m. The cost of the luncheon is $\$ 15$. Tickets may be reserved on the order form in the preliminary program.

\section{All-Conference Reception}

Enjoy an evening with your ACRL colleagues at the gala All-Conference Reception, Friday, April 7, 9:30 p.m.-11:30 p.m. The reception will be held at the Public Library of Cincinnati and Hamilton County, one of the top public research libraries in the country. Join your friends at the reception and enjoy jazz, desserts and after dinner liqueurs. The reception is generously funded by Baker \& Taylor.

\section{Celebrate the century with CJCLS}

Community and junior college librarians are invited to attend an informal, cash bar rendezvous for CJCLS members and friends at the Sun Garden Lounge of the Hyatt Hotel, on Thursday, April 6, 5:15 p.m.-7:00 p.m.

\section{Center for Research Libraries}

In honor of its fortieth anniversary, the Center will host a conference-wide reception on Thursday, April 6, 5:15 p.m.-7:00 p.m. The reception will be held in the third floor reception area of the Albert B. Sabin Cincinnati Convention Center.

\section{Library tours}

If you enjoy a busman's holiday, stop by the Hospitality Desk in the convention center to pick up a guide to the libraries within the Greater Cincinnati area. It explains how to get to the library of your choice with ease. The guide was prepared by the Local Arrangements Committee.

\section{Cincinnati tours}

Two tour possibilities have been arranged to suit your recreational interests. They are being pro- 


\section{Corporate and Industry Research Reports}

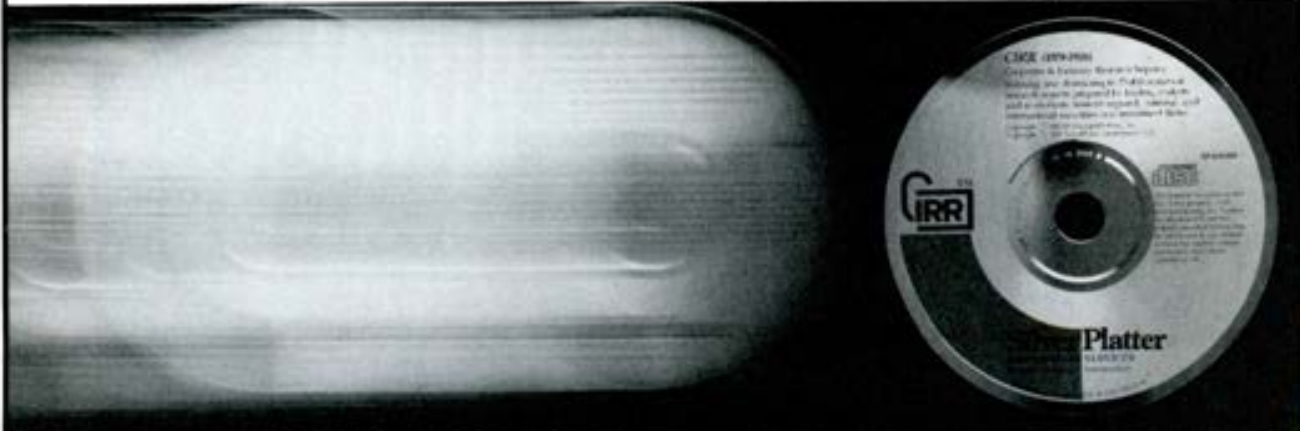

\section{The Fastest Growing Business Reference Service JUST GOT FASTER!}

Corporate and Industry Research Reports (CIRR), a collection of company and industry analytical research from 65 Wall Street investment banking firms is now available as CIRR on DISC. Over 100,000 research reports from 1979 forward are now key word and Boolean logic searchable.

Find Hallmark's market share, General Electric's cash flow position, growth potential for PC's, all in a matter of minutes.

Search Hard to Find subjects like market share, revenue by division or product line. Analyze financials over 10 years, trace a company's cash flow for the same period. review mergers and acquisitions, find out why products succeed or fail, compare management style and strategies for competing companies, analyze and reviow entire industries.
Now at your fingertips, ten years of a database on:

10,000 US companies

1,000 foreign companies

5,000 products or brands

610 industries

500 industry specific periodicals

Now features to the CIRR database:

- improved and expanded informative abstracts

- table of contents access to $\mathbf{5 0 0}$ periodicals

- business and industry periodical articles from Europe, Eastern Europe and the Soviet Union

- software subset feature to quickly search parts of the database, such as foreign companies

SllverPlatter Software operates the CIRR on DISC database. This is the same software that operates Eric, PsycLIT, sociofile, etc.

\section{Day FREE Trial}

Now take the opportunity to review CIRR ON DISC in your library. Your approval package includes CIRR on DISC, Software, Instruction Booklet. and sample full text reports on microfiche. CRLN-1

Please send CIRR Approval Kit | My CD Player is consisting of: CIRA on DISC. Search Strategies Booklet and corresponding sample microfiche. CIRR on DISC will be sent for a Thirty $(30)$ Day Free Trial. The Search Strategies Booklet and sample microfiche are complimentary. I understand that CIRR on DISC operates on an IBM compatible PC with $512 \mathrm{~K}$ or better memory.

My CD Player is $\quad$ Model \#
$\square$ YES $\square$ NO I request a CD Player with my 30 Day Trial.
Name
Institution
Address
City
Telophone ( $\quad$ State
Signature




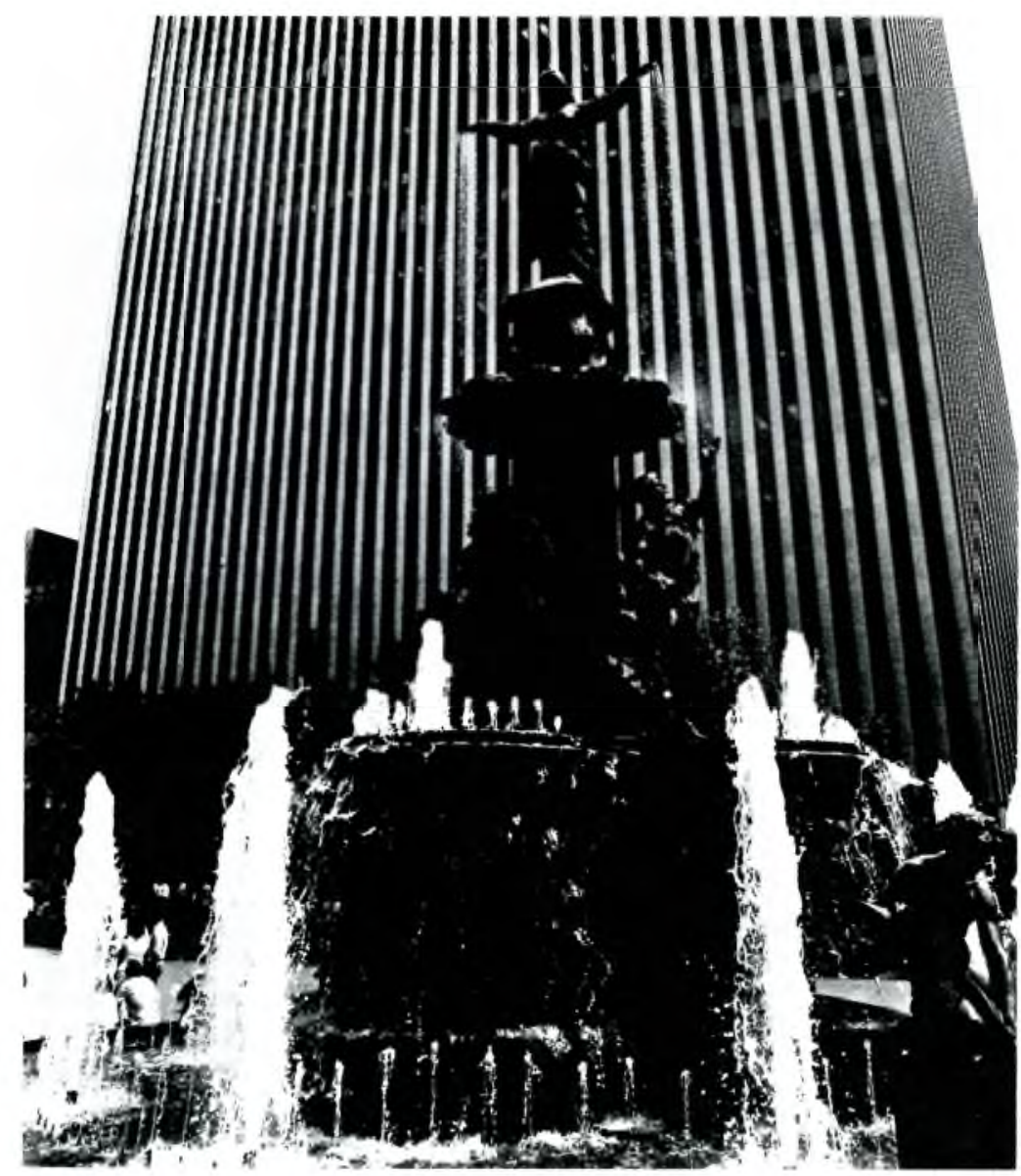

Historic Fountain Square blends the old and the new in downtown Cincinnati.

vided by Premier Events, 11695 Chesterdale Road, Cincinnati, $\mathrm{OH} 45246$. You may use the form provided in your registration packet to reserve space for these tours. The mail deadline is March 27, 1989.

BB Riverboat Cruise. For an evening to remember, board a BB riverboat in Covington, Kentucky, just across the river from downtown Cincinnati. This leisurely cruise on the famous Ohio River includes a delicious buffet dinner, music and the lovely old world scenery of both the Kentucky and the Ohio shores. Plan to attend with a group of your favorite ACRL friends. Thursday, April 6, 6:30 p.m. $-9: 30$ p.m., $\$ 21$, includes dinner.

Bus Tour of the City. Gaze at the highlights of Cincinnati and Northern Kentucky the easy wayvia a chartered bus! Boarding downtown near the conference hotels, you will see and hear about Fountain Square and many other downtown buildings and landmarks, including Music Hall and the Union Terminal. In picturesque nearby
Mt. Adams, see Rookwood Pottery, lovely Eden Park and a beautiful Ohio River overlook. Across the historic Suspension Bridge into Covington, Kentucky, you will view the restored Main Strasse area and several churches of historic renown. Finally, at the new Oldenberg Brewery, you will enjoy a show and lunch. Following a tour of this "Old World" brewery, you will return to the hotel area by 12:30 p.m. Wednesday, April 5, 9:00 a.m. $-12: 30$ p.m., $\$ 20$, includes lunch.

\section{Chapter meetings}

Three ACRL affiliated chapters will hold their spring meetings in conjunction with the ACRL National Conference. The College and University Division of the Indiana Library Association, the Academic Library Association of Ohio and the Academic Section of the Kentucky Library Association will each hold their business meeting on Thursday, April 6, 5:15 p.m.-6:15 p.m. 


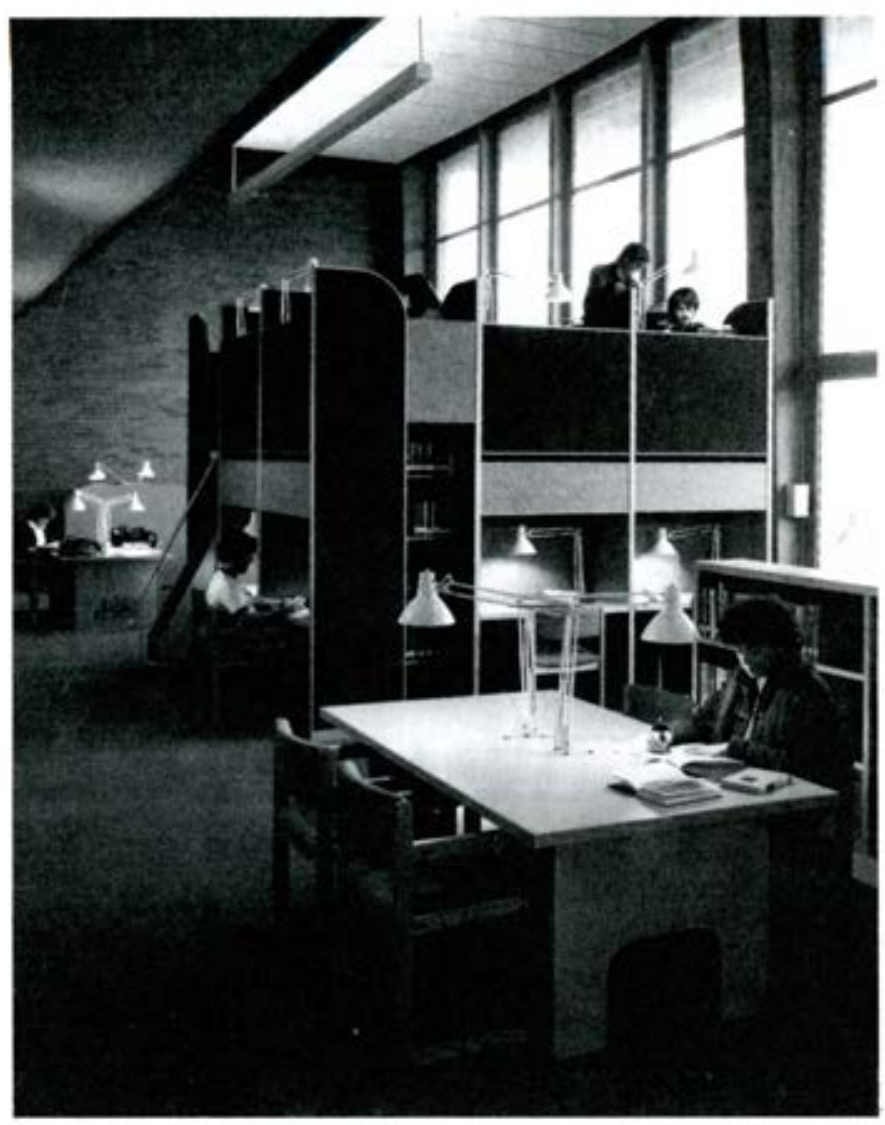

\section{.... a better approach to the use of space}

FOR INFORMATION ON THIS AND OTHER INNOVATIVE FURNITURE, PLEASE WRITE OR CALL M̈ÖHÄ K MiDLÄD̃ MÄNÜFACTURING

7733 GROSS POINT ROAD P.O. BOX 226 SKOKIE, IL 60076-0226 PHONE (312) 677-0333 TELEX 28-9429 


\section{Springer-Verlag \\ — Publishing New Ideas}

Throughout the medical and scientific world, Springer-Verlag has an established reputation as the publisher of outstanding books and journals.

Since 1842 Springer-Verlag has had its finger on the pulse of the international market. In addition to offices in Berlin and Heidelberg, Springer-Verlag has branches in New York, Vienna, Tokyo, London, Paris, and Hong Kong. Over 12,000 titles are now in print, with an additional 1,500 new titles released yearly.

New York Office Now 25 Years Old

Located in the historic Flatiron Building, this office annually publishes over 250 books, 45 journals, and several magazines. Excellence in production and increasing emphasis on English as the scientific language of choice has strengthened the impact of SpringerVerlag New York upon the North American medical and scientific community.

\section{Available Through Your Wholesaler}

Springer-Verlag books and journals are available through your wholesaler or subscription agent. For further information about SpringerVerlag visit Mary Fugle, Sales Manager Libraries, Wholesalers, and Journals at our booth or call (212) 460-1594. 


\section{Preconference on regional history collections}

"Local History, Global Village: Regional Collecting, Regional Collections" is the theme of the ACRL Rare Books and Manuscripts Section's preconference, set for June 22-23, 1989, on the campus of Southern methodist University in Dallas.

Donald J. Pisani, associate professor of history at Texas A\&M University and author of From the Family Farm to Agribusiness: The Irrigation Crusade in California and the West, 1850-1931, will give the keynote address. Pisani will explore the difficulties of collecting an ever-increasing mass of documents pertaining to the region's history at public, academic, and state agency libraries and institutional archives. Other presentations will examine regional cooperation and the need to coordinate collection development, documentation strategies, and the experiences of a variety of institutions and libraries with extensive regional collections.

Preconference activities include receptions on
Thursday and Friday evenings and a dinner on Friday. Housing will be available in the SMU dormitories for $\$ 16$ a night or in any of the ALA conference hotels in downtown Dallas. All program sessions will take place on the SMU campus, so there will be no official RBMS hotel for the Dallas preconference.

Registration for the preconference is limited to the first 200 applicants. The fee is $\$ 85$ for ACRL members and $\$ 110$ for non-members. The deadline is May 15, 1989. Late registration will be accepted on a space available basis after May at an additional cost of $\$ 25$ per person.

A registration brochure will be mailed to all RBMS members. Additional brochures and information may be requested by contacting Mary Ellen Davis, RBMS Preconference, ACRL/ALA, 50 E. Huron St., Chicago, IL 60611-2795; (800) 5452433; in Illinois, (800) 545-2444; in Canada, (800) 545-2455.

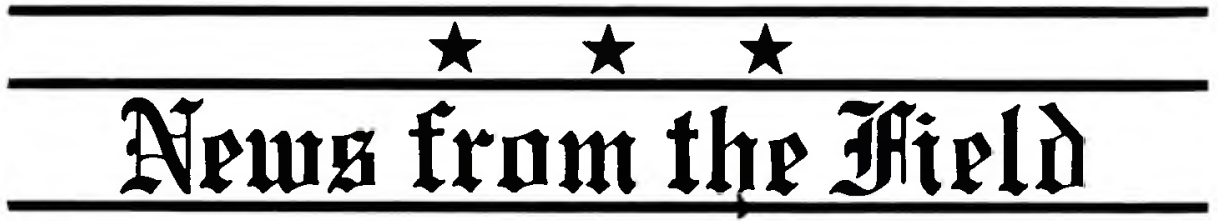

\section{Acquisitions}

- The College of William and Mary's Earl Gregg Swem Library, Williamsburg, Virginia, has acquired the Murray and Shirley G. Horowitz Collection on Dogs and Related Subjects, a gift from Shirley G. Horowitz, of North Woodmere, New York. The collection contains some 6,000 volumes and will complement the Peter Chapin Collection of Books about Dogs presented to William and Mary in 1937.

- East Central State University, Ada, Oklahoma, has acquired 71 volumes of typescripts of proceedings and document books pertaining to Cases One and Eight of the Nazi War Crimes Trials heard by Tribunal One of the United States Military Tribunal at Nuremberg, Germany, 1946-1947. The set, donated by Mr. and Mrs. Thomas Elwood Kemp of Ada, belonged to Johnson Tal Crawford, a local Pontotoc County district judge who was one of the three judges who made up Tribunal One. In some cases the books contain Crawford's handwritten notes about the evidence and the disposition of a case. Document books for Case One, the case against the doctors, also include photographs of victims of medical experiments.
These volumes join other personal papers of Crawford's acquired by the University some years ago.

-The National Library of Medicine, Bethesda, Maryland, has acquired a copy of the book describing the discovery of oxygen in 1773 by the Swedish apothecary Carl Wilhelm Scheele (1742-1786), who isolated the gas prior to and independently of Joseph Priestley, the British scientist credited with the discovery in 1774. Although the manuscript for Scheele's Chemische Abhandlung von der Luft und dem Feuer was ready for the printer by December 1775 , publication was delayed for two years and he did not publish his results until 1777. The book is extremely rare and NLM has been fortunate to acquire a copy in fine condition.

- Ohio State University's Edgar Dale Media Center, Columbus, has acquired a collection of 4,000 children's books from professor Charlotte Huck, who retired in June 1988. This teaching and research collection, recently appraised at $\$ 21,000$, traces the development of children's literature from 1820 to the present. The collection includes works by Caldecott, Crane, Greenaway, Potter, and Baum, along with significant picture books, classics, special reference books, and Mother Goose Collections. Two original woodblocks, valued at $\$ 400$ each, of Randolph Caldecott's illustrations 